\title{
Uji Toksisitas Ekstrak Etanol Daun Ekor Kucing (Acalypha hispida Burm.f.) Dengan Metode Brine Shrimp Lethality Test (BSLT)
}

\author{
Hadi Kurniawan ${ }^{*}$, Meri Ropiqa ${ }^{2}$ \\ ${ }^{1}$ Program Studi Farmasi, Fakultas Kedokteran, Universitas Tanjungpura, Jalan Prof. Dr. H. Hadari \\ Nawawi, Pontianak, Kalimantan Barat, Indonesia \\ 2Program Studi Teknologi Laboratorium Medis, Politeknik 'Aisyiyah Pontianak, Jalan Ampera, \\ Pontianak Kalimantan Barat, Indonesia \\ *Penulis Korespondensi. Email: hadi.kurniawan@pharm.untan.ac.id
}

\section{ABSTRAK}

Daun Ekor Kucing (Acalypha hispida Burm.f.) merupakan jenis tanaman hias yang telah dikenal masyarakat Indonesia untuk pengobatan, namun belum ada penelitian untuk meneliti toksisitas akut daun ekor kucing. Tanaman ini mengandung senyawa alkaloid dan flavonoid. Tujuan dari penelitian ini adalah untuk mengetahui potensi ketoksikan akut ekstrak etanol daun ekor kucing (A. hispida Burm.f.) terhadap larva Artemia salina Leach dengan metode Brine Shrimp Lethality Test (BSLT) yang ditunjukkan dengan nilai LC $_{50}$. Penelitian eksperimental ini menggunakan 300 ekor larva udang (Artemia salina Leach) yang dibagi menjadi 5 kelompok kontrol negatif dan 5 kelompok seri konsentrasi ekstrak. Masing-masing kelompok terdiri dari 10 ekor larva dengan replikasi 3 kali untuk tiap kelompok perlakuan. Kelima kelompok perlakuan diberi suspensi sediaan uji ekstrak etanol daun ekor kucing dengan konsentrasi 100 ppm, 250 ppm, 500 ppm, 750 ppm, dan 1.000 ppm. Data kematian Artemia salina Leach dianalisis dengan analisis probit untuk mengetahui nilai $\mathrm{LC}_{50}$. Hasil penelitian ini menunjukkan harga $\mathrm{LC}_{50}$ dari ekstrak etanol daun ekor kucing adalah 220,005 ppm. Ekstrak etanol daun ekor kucing memiliki potensi toksisitas akut terhadap larva Artemia salina Leach menurut metode BSLT yang ditunjukkan dengan harga $\mathrm{LC}_{50}<1.000 \mathrm{ppm}$.

Kata Kunci:

Uji toksisitas akut, Acalypha hispida Burm.f., BSLT, Artemia salina Leach

$\begin{array}{lcc}\text { Diterima: } & \text { Disetujui: } & \text { Online: } \\ 17-08-2021 & 30-08-2021 & 30-08-2021\end{array}$

\section{ABSTRACT}

Acalypha hispida Burm.f. is a flowering shrub commonly planted as decorative aimed. In Indonesia, it is well used as medication due to its medicinal beneficiary. The medicinal activity of A. hispida was known related to alkaloids and flavonoid contents. However, the toxicity of that activity is obscure. Objectives: This research is aimed to revealed the acute toxicity properties of ethanolic extract of $A$. hispida leaves. Material and Methods: Test was carried out on Artemia salina larvae by Brine Shrimp Lethality Test (BSLT). Toxicity properties was showed as $L C_{50}$ value. This experimental research was conducted to 300 larvae which divided into 5 groups of negative control and 5 groups treatment of extract dilution series. Each group was consisted of 10 larvae. All treatments were conducted in 3 replications. Those five dilution series exposed were 100 ppm; 250 ppm; 500 ppm; 750 ppm; and 1.000 ppm respectively. Lethal number of the larva was counted and analyzed by probit analysis to determine the $L C_{50}$ value. Results: The obtained $L C_{50}$ value of ethanolic extract of $A$. hispida leaves was 220,005 ppm. Conclusions: As the value less than 1.000 ppm, this result indicated the ethanolic extract has the acute toxicity on Artemia salina Leach larvae by BSLT bioassay method 


\begin{tabular}{|c|c|c|}
\hline \multicolumn{3}{|c|}{$\begin{array}{l}\text { Keywords: } \\
\text { The acute toxicity, Acalypha hispida Burm.f., BSLT, Artemia salina Leach }\end{array}$} \\
\hline $\begin{array}{l}\text { Received: } \\
\text { 2021-08-17 }\end{array}$ & $\begin{array}{l}\text { Accepted: } \\
\text { 2021-08-30 }\end{array}$ & $\begin{array}{c}\text { Online: } \\
\text { 2021-08-30 }\end{array}$ \\
\hline
\end{tabular}

\section{Pendahuluan}

Dewasa ini, walaupun obat-obat modern telah mendominasi pelayanan kesehatan formal, penggunaan obat tradisional tetap mendapat tempat yang penting bahkan terus berkembang. Obat tradisional tidak dapat dipisahkan dari kehidupan kita karena sudah lekat dengan budaya bangsa dan digunakan oleh segenap lapisan masyarakat. Sesuai standar mutu dari WHO, obat tradisional harus memenuhi beberapa persyaratan meliputi kualitas, keamanan, dan khasiat [1]. Penggunaan bahan alam sebagai obat tradisional di masyarakat dijamin keamanannya oleh pemerintah dengan Permenkes No.760/Menkes/Per/IX/1992, tentang obat tradisional dan fitofarmaka [2]. Sebelum menjadi suatu sediaan fitofarmaka, setiap bahan alam harus melewati beberapa tahapan meliputi uji farmakologi eksperimental, uji toksisitas, uji klinis, uji kualitas dan pengujian lainnya sesuai persyaratan demi keamanan pengguna [3].

Ekor kucing merupakan tanaman asli dari Hindia Barat. Umumnya, ditanaman sebagai tanaman hias di halaman atau di taman-taman. Ekor kucing telah dikenal oleh masyarakat untuk pengobatan bercak putih di kulit (vitiligo), disentri, batuk darah, sariawan, disentri, dan mimisan [4]. Bagian tanaman yang digunakan pada penelitian ini adalah bagian daun ekor kucing. Mengingat pemanfaatan daun ekor kucing yang beragam tetapi masih berdasarkan pengalaman secara turun-temurun, maka masih perlu didukung informasi ilmiah mengenai potensi toksisitas akut.

Penelitian uji toksisitas akut ekstrak etanol daun ekor kucing terhadap larva Artemia salina Leach menggunakan metode Brine Shrimp Lethality Test (BSLT). Metode BSLT dipilih karena metode ini sering digunakan untuk praskrining terhadap senyawa aktif yang terkandung dalam ekstrak tumbuhan karena sederhana, cepat, murah, mudah, dapat dipercaya, dan hasilnya representatif [5]. Uji toksisitas dengan menggunakan BSLT ini dapat ditentukan dari jumlah kematian Artemia salina Leach akibat pengaruh ekstrak atau senyawa bahan alam. Hasil uji dinyatakan sebagai $\mathrm{LC}_{50}$.

Berdasarkan latar belakang diatas maka penelitian ini diusulkan dengan tujuan untuk mengetahui potensi ketoksikan akut ekstrak etanol daun ekor kucing terhadap larva Artemia salina Leach dengan metode Brine Shrimp Lethality Test (BSLT) yang ditunjukkan dengan nilai $\mathrm{LC}_{50}$. Uji toksisitas terhadap larva udang Artemia salina Leach atau Brine Shrimp Lethallity Test (BSLT) dapat digunakan sebagai uji pendahuluan pada pengujian bioaktivitas lebih lanjut.

\section{Metode}

\subsection{Bahan dan Alat}

Bahan-bahan yang diperlukan dalam penelitian ini adalah daun ekor kucing (Acalypha hispida Burm.f.), telur udang Artemia salina Leach, etanol teknis (E. Merck $\left.{ }^{\circledR}\right)$, reagen mayer, reagen dragendorff (E. Merck $\left.{ }^{\circledR}\right)$, DMSO 1\%, akuades dan ragi (Fermipan $\left.{ }^{\circledR}\right)$. 
Alat-alat yang digunakan untuk penelitian ini adalah neraca analitik (Precisa XB 4200 $\mathrm{C}^{\circledR}$, alat-alat gelas $\left(\right.$ Pyrex $\left.^{\circledR}\right)$, pipet mikro, rotary evaporator (Heidolph ${ }^{\circledR}$ ), desikator, vortex (Maxi Mix II Barnstead Thermolyne Type 37600 Mixer ${ }^{\circledR}$ ), mikroskop (Zeiss Primo Star ${ }^{\circledR}$ dilengkapi kamera dan program Axio Cam), indikator $\mathrm{pH}$, termometer, lampu pijar/neon 40-60 watt, plat KLT/lempeng silika gel 60 GF254 (E. Merck ${ }^{\circledR}$ ), chamber, pipa kapiler, alat semprot, dan lampu UV 254 dan $366 \mathrm{~nm}$.

\section{2..2 Ekstraksi Daun Ekor Kucing}

Pembuatan ekstrak etanol daun ekor kucing (Acalypha hispida Burm.f.). Ekstraksi dilakukan dengan metode maserasi. Simplisia daun ekor kucing dengan direndam dengan penyari etanol teknis, kemudian ditutup dan didiamkan selama 24 jam dan dilakukan selama 3 hari, maserat ditampung dan selanjutnya maserat dievaporasi dengan rotary evaporator hingga didapatkan ekstrak kering daun ekor kucing. Selanjutnya ekstrak diuji sisa pelarut, skrining fitokimia dengan uji tabung dan dilanjutkan dengan uji pemisahan dengan KLT.

\subsection{Pembuatan Air Laut Buatan (ALB)}

Air laut buatan disiapkan dengan melarutkan 15 gram $\mathrm{NaCl}$ dalam 1 liter aquades.

\subsection{Penetasan Telur Artemia salina Leach}

Telur udang ditetaskan 2 hari sebelum dilakukan uji. Disiapkan bejana untuk penetasan telur udang. Wadah yang digunakan dibagi menjadi dua bagian, bagian gelap dan terang kemudian ditambahkan air laut buatan. Satu ruang dalam bejana tersebut diberi penerangan dengan cahaya lampu pijar/neon 40-60 watt untuk menghangatkan, sedangkan di ruang sebelahnya diberi air laut buatan tanpa penyinaran ditutup dengan aluminium foil. Telur yang telah dicuci ditempatkan/direndam pada bagian gelap dari wadah berisi air laut buatan sekitar $300 \mathrm{~mL}$. Telur udang yang terendam air laut buatan dibiarkan selama $2 \times 24$ jam sampai menetas menjadi benur (nauplius).

\subsection{Uji Toksisitas dengan Metode BSLT}

Vial disediakan untuk tiap kelompok sesuai peringkat konsentrasi dengan masingmasing disediakan 5 vial dan direplikasi sebanyak 3 kali. Ekstrak yang akan diuji dibuat dalam konsentrasi 100, 250, 500, 750, 1.000 ppm dalam air laut buatan serta kelompok kontrol negatif dengan konsentrasi 0 ppm yaitu hanya pelarutnya tanpa penambahan ekstrak. Vial yang berisi larutan uji dikeringkan sampai semua pelarutnya menguap selama beberapa hari pada suhu kamar dalam desikator sehingga tidak berbau pelarut dan dapat ditunjukkan dengan proses pengeringan menghasilkan penimbangan yang konstan. Kemudian ditambahkan DMSO 1\% 1-3 tetes (50-150 $\mu \mathrm{L})$ termasuk vial kontrol untuk melarutkan sampel. Selanjutnya vial yang telah diisi sampel kemudian ditambah air laut buatan $1 \mathrm{~mL}$ dan divortex sekitar 30 menit, kemudian 10 ekor larva udang Artemia salina Leach yang berumur 48 jam dimasukan dalam vial. Satu tetes ragi $(0,6$ $\mathrm{mg} / \mathrm{mL}$ ) dimasukkan ke dalam setiap vial sebagai makanan Artemia, lalu ditambahkan air laut buatan sampai tanda batas volume $5 \mathrm{~mL}$. Kriteria standar untuk menilai kematian larva udang adalah bila larva udang tidak menunjukkan pergerakan selama beberapa detik observasi. Cara manual yaitu dengan mengamati larva di dalam vial 
dengan bantuan lup, kemudian diamati dalam kaca arloji dengan bantuan cahaya. Jumlah nauplii yang mati dihitung dengan mengurangkan jumlah total nauplii pada tiap konsentrasi dengan jumlah nauplii yang masih hidup. Sedangkan cara mikroskopik adalah dilakukan pengamatan di bawah mikroskop.

\subsection{Analisis Toksisitas}

Efek toksik diperoleh dari pengamatan dengan menghitung \% kematian (mortalitas) larva Artemia salina Leach pada tiap konsentrasi dalam 24 jam. Persen kematian diperoleh dari hasil perkalian rasio dengan 100\%, yaitu larva yang mati dibagi jumlah larva awal dikali 100\% untuk tiap replikasi. Lalu dibandingkan dengan kontrol dan dilakukan analisis hasil dengan analisis probit sehingga diperoleh harga $\mathrm{LC}_{50}$.

\section{Hasil dan Pembahasan}

\subsection{Ekstraksi Daun Ekor Kucing}

Daun ekor kucing (Acalypha hispida Burm.f.) yang digunakan berbetuk simplisia kering. Simplisia yang telah kering ini berwarna hijau dan dihaluskan sehingga diperoleh serbuk daun ekor kucing dengan tujuan untuk mempermudah proses ekstraksi. Simplisia daun ekor kucing ini selanjutnya dianalisis kadar airnya dengan cara mengeringkan simplisia dalam oven pada suhu $105{ }^{\circ} \mathrm{C}$ selama 5 jam untuk menghilangkan kadar airnya, simplisia disimpan dalam desikator sekitar 10 menit, kemudian ditimbang dan dilakukan perlakuan yang sama sampai diperoleh berat konstan. Tercapainya berat yang konstan menunjukkan air yang terdapat dalam tanaman telah teruapkan secara maksimal. Kadar air yang dikandung simplisia daun ekor kucing yaitu 7,39 \% sehingga simplisia daun ekor kucing pada proses penyimpanan terhindar dari kerusakan akibat degradasi oleh mikroorganisme maupun penguraian oleh enzim dapat diminimalkan. Kadar air ditetapkan untuk menjaga kualitas simplisia. Menurut Voight [6], bahwa kadar air dalam ekstrak tidak boleh lebih dari 10\%. Bila kadar air yang terkandung dalam suatu bahan/sampel organik kurang dari 10\% maka pertumbuhan mikroba dan jamur dapat dikurangi. Selain itu, kadar air yang lebih sedikit memudahkan cairan pengekstrak masuk ke dalam sel dan menarik zat aktif daun ekor kucing yang terkandung secara sempurna. Simplisia yang telah dihilangkan kadar airnya cenderung mudah menyerap air sehingga simplisia daun ekor kucing yang telah kering ini disimpan dalam tempat yang kedap udara.

Simplisia diekstraksi dengan metode maserasi. Didapatkan hasil ekstrak pekat berwarna kecoklatan, berkonsistensi kering, dan berasa sepat sebanyak 100,62 g (rendemen 20,124 \%). Penentuan organoleptik ini termasuk salah satu parameter spesifik yang ditentukan dengan menggunakan panca indera dan bertujuan untuk pengenalan awal secara sederhana dan subjektif. Setelah didapatkan ekstrak dilakukan penetapan standar mutu dan kandungan kimia ekstrak. Standardisasi ini dimaksudkan agar dapat menjamin bahwa produk ekstrak mempunyai nilai parameter tertentu yang konstan. Pengujian yang penting dilakukan adalah uji sisa pelarut yang terkandung dalam ekstrak etanol daun ekor kucing dengan cara susut pengeringan. Uji ini dilakukan untuk mengetahui jenis ekstrak dan memberikan batasan maksimal tentang besarnya pelarut yang hilang pada proses pengeringan. Kadar pelarut yang tersisa yaitu 4,97 \% sehingga ekstrak etanol daun ekor kucing yang digunakan termasuk ekstrak kering 
karena sisa pelarut < 5\% [6]. Ekstrak kering (Extractum siccum) merupakan sediaan yang memiliki konsistensi kering dan mudah digosokkan.

Ekstrak kering daun ekor kucing selanjutnya diuji dengan skrining fitokimia menggunakan uji tabung dan uji identifikasi fitokimia dengan Kromatografi Lapis Tipis (KLT). Skrining fitokimia ini dilakukan untuk mengetahui kandungan senyawa metabolit sekunder berdasarkan perubahan warna atau terbentuknya endapan yang dihasilkan sebagai akibat penambahan reagen tertentu. Pada penelitian ini pengujiannya dilakukan dengan cara mengambil sampel secukupnya dari ekstrak etanol pada tabung reaksi, lalu ditambahkan reagen sesuai dengan senyawa yang akan diidentifikasi.

Tabel 1. Hasil Pengamatan Uji Skrining Fitokimia Ekstrak Etanol Daun Ekor Kucing (Acalypha hispida Burm.f.)

\begin{tabular}{|c|c|c|c|c|}
\hline No & Kandungan kimia & Pereaksi & Hasil & Kesimpulan \\
\hline \multirow[t]{3}{*}{1} & Alkaloid & Mayer & endapan putih & + \\
\hline & & & kekuningan & \\
\hline & & Dragendorf & $\begin{array}{l}\text { endapan jingga- } \\
\text { merah bata }\end{array}$ & + \\
\hline 2 & Flavonoid & $\mathrm{HCl} / \mathrm{Mg}$ & warna merah & ++ \\
\hline
\end{tabular}

\section{Keterangan:}

$++\quad$ : terkandung senyawa lebih banyak/warna pekat/endapan banyak

$+\quad$ : terkandung senyawa/warna muda/endapan sedikit

- $\quad$ : tidak terkandung senyawa/tidak terbentuk warna

Sebagaimana yang ditunjukkan pada tabel 1 hasil uji skrining fitokimia ekstrak etanol daun ekor kucing menunjukkan adanya senyawa alkaloid dan flavonoid. Adanya senyawa alkaloid dan flavonoid dalam ekstrak etanol daun ekor kucing telah teruji dengan pengujian skrining fitokimia menggunakan reagen uji tabung [8]. Pembuktian kandungan senyawa-senyawa tersebut diperkuat dengan adanya identifikasi menggunakan Kromatografi Lapis Tipis (KLT). KLT pada penelitian ini dilakukan untuk mempertegas adanya kandungan senyawa alkaloid dan flavonoid pada ekstrak etanol daun ekor kucing (Acalypha hispida Burm.f.). Hasil KLT dapat ditunjukkan dalam Tabel 2. 
Tabel 2. Hasil KLT dengan Fase Diam Silika Gel $60 \mathrm{~F}_{254}$ Ekstrak Etanol Daun Ekor Kucing (Acalypha hispida Burm.f.)

\begin{tabular}{ccccc}
\hline $\begin{array}{c}\text { Kandungan } \\
\text { kimia }\end{array}$ & \multicolumn{1}{c}{ UV 254 } & UV 366 & Semprot & Kesimpulan \\
\hline Alkaloid & $\begin{array}{l}\text { Meredam bercak, } \\
\text { bercak biru gelap } \\
\text { dengan latar } \\
\text { belakang kuning }\end{array}$ & $\begin{array}{l}\text { Berfluoresensi / } \\
\text { berpendar }\end{array}$ & $\begin{array}{c}\text { Dragendorf: } \\
\text { Kuning/jingga- } \\
\text { Hijau }\end{array}$ & $\begin{array}{c}\text { Mengandung } \\
\text { Alkaloid }\end{array}$ \\
Flavonoid & $\begin{array}{l}\text { Meredam bercak, } \\
\text { bercak biru gelap } \\
\text { dengan latar } \\
\text { belakang kuning }\end{array}$ & Berfluoresensi / & - & $\begin{array}{c}\text { Mengandung } \\
\text { Flavonoid }\end{array}$ \\
& & & & \\
\hline
\end{tabular}

Hasil identifikasi menggunakan KLT terhadap golongan senyawa alkaloid ekstrak etanol daun ekor kucing dengan menggunakan eluen/fase gerak etil asetat-metanol-air (100:13,5:10) dapat ditunjukkan pada gambar 1 berikut.

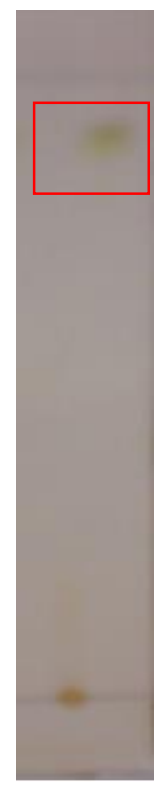

Hasil Elusi Sebelum UV

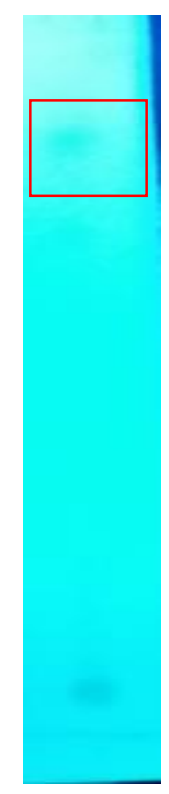

UV $254 \mathrm{~nm}$

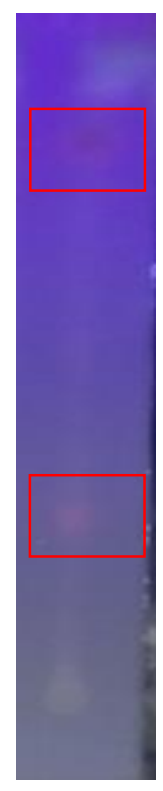

UV $366 \mathrm{~nm}$

Gambar 1. Uji kandungan golongan senyawa alkaloid dengan Kromatografi Lapis Tipis (KLT) dengan eluen etil asetat-metanol-air (100:13,5:10)

Keterangan:

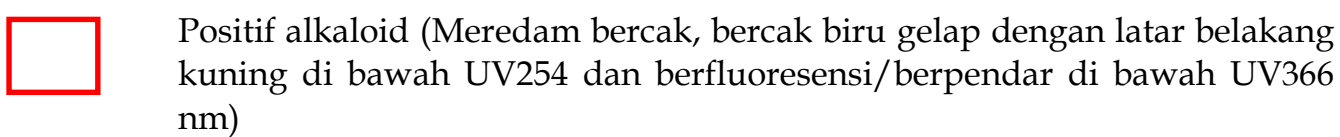

Gambar 1 di atas menunjukkan hasil identifikasi kandungan senyawa aktif pada ekstrak etanol daun ekor kucing menunjukkan adanya senyawa alkaloid. Ekstrak mengandung alkaloid bebas bila dilihat di bawah sinar UV254 meredam bercak, sehingga terlihat 
bercak biru gelap dengan latar belakang kuning pada lempeng KLT di bawah UV254. Sedangkan pada UV366 nm berflouresensi hijau/berwarna coklat/jingga atau merah dengan perekasi Dragendorf $[7,8]$.

Hasil identifikasi menggunakan KLT golongan senyawa flavonoid ekstrak etanol daun ekor kucing dengan menggunakan eluen/fase gerak kloroform-etil asetat (6:4) dapat ditunjukkan pada gambar 2 berikut.

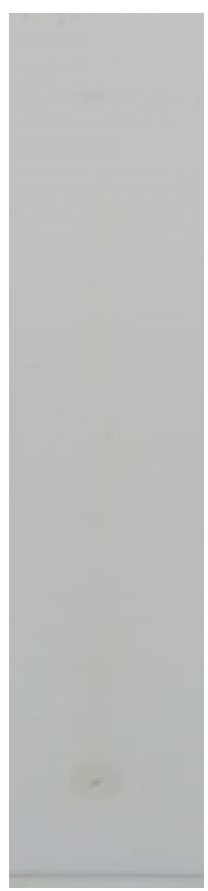

Hasil Elusi Sebelum UV

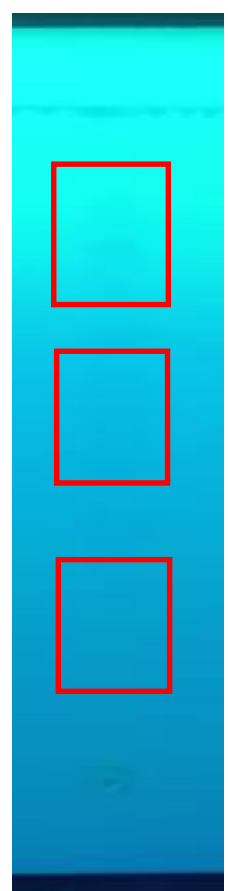

UV 254 nm

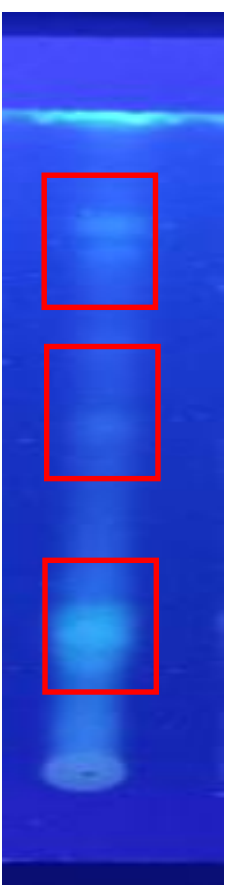

UV 366 nm

Gambar 2. Uji kandungan golongan senyawa Ffavonoid dengan Kromatografi Lapis Tipis (KLT) dengan eluen kloroform-etil asetat (6:4)

Keterangan:

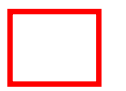

Positif flavonoid (Meredam bercak, bercak biru gelap dengan latar belakang kuning di bawah UV254 dan berfluoresensi/berpendar di bawah UV366 nm)

Gambar 2 di atas menunjukkan hasil identifikasi kandungan senyawa aktif pada ekstrak etanol daun ekor kucing menunjukkan adanya senyawa flavonoid. Semua flavonoid menyebabkan pemadaman, sehingga terlihat bercak biru gelap dengan latar belakang kuning pada lempeng KLT dibawah UV254. Sedangkan pada UV366 flavonoid berfluoresensi/berpendar hijau atau biru atau kuning atau biru kehijauan [7, 9, 10, 11]. Hasil identifikasi kandungan senyawa aktif pada ekstrak etanol daun ekor kucing dengan KLT menunjukkan adanya senyawa alkaloid dan flavonoid. 


\subsection{Uji Toksisitas Ekstrak Dengan Metode Brine Shrimp Lethality Test (BSLT)}

Brine Shrimp Lethality Test (BSLT) merupakan uji pendahuluan/praskrining aktivitas biologis yang sederhana untuk menentukan toksisitas suatu senyawa atau ekstrak secara akut menggunakan hewan coba larva udang (Artemia salina nauplii). Parameter yang ditunjukkan untuk menunjukkan adanya aktivitas biologi pada suatu senyawa pada Artemia salina Leach adalah jumlah kematian larva udang karena pengaruh pemberian senyawa dengan dosis yang telah ditentukan. Salah satu organisme yang sangat sesuai sebagai hewan uji untuk mengetahui bioaktivitas senyawa melalui uji toksisitas adalah brine shrimp (udang laut) dari jenis Artemia salina Leach. Uji ini menggunakan larva udang laut atau nauplii. Beberapa kelebihan dari uji bioaktivitas dengan Brine Shrimp Lethallity Test (BSLT) menggunakan larva udang Artemia salina Leach adalah cepat waktu ujinya, mudah, tidak memerlukan peralatan khusus, sederhana (tanpa teknik aseptik), murah (tidak perlu serum hewan), jumlah organisme banyak, memenuhi kebutuhan validasi statistik dengan sedikit sampel, hasilnya representatif dan dapat dipercaya [5].

Larutan ekstrak etanol daun ekor kucing dibuat dengan konsentrasi 100 ppm, 250 ppm, 500 ppm, 750 ppm, dan 1.000 ppm serta sebagai kelompok pengontrolnya 0 ppm yaitu hanya berisi pelarutnya tanpa penambahan ekstrak. Larutan kontrol berfungsi untuk menghilangkan pengaruh lain diluar ekstrak uji yang dapat menyebabkan kematian nauplius. Pada penelitian ini digunakan 300 ekor larva uji. Rata-rata kematian larva untuk masing-masing kelompok perlakuan diperoleh dengan menghitung total jumlah kematian setiap kelompok perlakuan sebanyak 3 replikasi dan kemudian membaginya dengan jumlah replikasi.

Tabel 3. Hasil analisis brine shrimp lethality test (BSLT) ekstrak daun ekor kucing

\begin{tabular}{cccc}
\hline $\begin{array}{c}\text { Konsentrasi } \\
\text { ekstrak (ppm) }\end{array}$ & $\begin{array}{c}\text { Akumulasi } \\
\text { kematian }\end{array}$ & Mortalitas (\%) & LC $_{50}(\mathrm{ppm})$ \\
\hline 1.000 & 26 & 86,6 & \\
750 & 25 & 83,3 & 220,005 \\
500 & 20 & 66,6 & \\
250 & 14 & 46,6 & \\
100 & 10 & 33,3 & \\
Kontrol & 0 & 0 & \\
\hline
\end{tabular}

Tabel 3 menunjukkan bahwa peningkatan konsentrasi berbanding lurus dengan peningkatan mortalitas sehingga daya bunuh semakin tinggi. Suatu senyawa dinyatakan mempunyai potensi toksisitas akut jika mempunyai harga $\mathrm{LC}_{50}$ kurang dari $1.000 \mu \mathrm{g} / \mathrm{ml}$ (ppm). LC 50 (Lethal Concentration 50) merupakan konsentrasi zat yang 
menyebabkan terjadinya kematian pada $50 \%$ hewan percobaan yaitu larva Artemia salina Leach. Sebagaimana yang ditunjukkan oleh Tabel 3 pengujian terhadap ekstrak etanol daun ekor kucing (Acalypha hispida Burm.f.) menunjukkan harga LC $_{50}$ sebesar $220,005 \mu \mathrm{g} / \mathrm{ml}$ atau ppm, sehingga dapat dikatakan ekstrak etanol daun ekor kucing (Acalypha hispida Burm.f.) pada percobaan ini memiliki potensi toksisitas akut menurut metode BSLT yaitu pada perlakuan dengan hewan coba larva Artemia salina Leach. Penelitian Meyer [5], melaporkan bahwa suatu ekstrak menunjukkan aktivitas ketoksikan dalam BSLT jika ekstrak dapat menyebabkan kematian $50 \%$ hewan uji pada konsentrasi kurang dari 1.000 ppm [5]. Nilai LC $_{50}$ dari ekstrak etanol yang lebih kecil dari 1.000 ppm menunjukkan bahwa ekstrak tersebut mempunyai potensi untuk dapat dikembangkan. Hal tersebut berkaitan dengan senyawa yang terdapat dalam daun ekor kucing yaitu alkaloid dan flavonoid dimana pada kadar tertentu memiliki potensi toksisitas akut serta dapat menyebabkan kematian larva Artemia salina Leach.

Mekanisme kerja kematian larva diperkirakan bahwa senyawa-senyawa yang terdapat pada ekstrak daun ekor kucing dapat menghambat daya makan larva (antifedant) dengan cara bertindak sebagai stomach poisoning (racun perut). Oleh karena itu, bila senyawa-senyawa ini masuk ke dalam tubuh larva udang, alat pencernaannya akan terganggu [3]. Racun perut menyerang organ utama pencernaan serangga yaitu bagian ventrikulus [12]. Senyawa alkaloid memiliki karakter toksin, repellent dan antifeedant pada serangga sehingga mengganggu pertumbuhan dan perkembangan larva. Dalam jumlah sedikit alkaloid hanya bersifat antifeedant dan membunuh larva secara perlahan karena menurunnya nafsu makan dan baru akan menyebabkan kematian dalam beberapa waktu karena kelaparan. Tetapi dalam jumlah besar alkaloid bekerja sebagai racun kontak dan racun pencernaan yang akan langsung membunuh larva dan menyebabkan kematian karena menyerang organ vital seperti sistem syaraf dan mempengaruhi aktivitas jantung. Senyawa flavonoid memiliki cara kerja sebagai racun pernafasan dan racun metabolisme yang dapat langsung menyebabkan kematian dalam waktu singkat [13]. Senyawa flavonoid dapat menghambat saluran pencernaan serangga dan juga bersifat toksik [14]. Selain itu, senyawa ini menghambat reseptor perasa pada daerah mulut larva. Hal ini mengakibatkan larva gagal mendapatkan stimulus rasa sehingga tidak mampu mengenali makanannya sehingga larva mati kelaparan ([15][16]).

Senyawa yang ada pada ekstrak dapat masuk melalui bagian mulut Artemia salina dan diabsorbsi masuk ke dalam saluran pencernaan melalui membran sel, kemudian dilanjutkan dengan proses distribusi senyawa toksik ke dalam tubuh Artemia salina, dan terjadi proses kerusakan pada reaksi metabolisme. Struktur anatomi tubuh Artemia salina pada tahap naupli masih sangat sederhana, yaitu terdiri dari lapisan kulit, mulut, anthena, saluran pencernaan dan calon thoracopoda. Perubahan gradien konsentrasi antara di dalam dan di luar sel yang menyebabkan senyawa toksik mampu menyebar dengan cepat ke tubuh Artemia salina. Efek kerusakan metabolisme yang ditimbulkan 
terjadi secara cepat dapat dideteksi dalam waktu 24 jam, hingga menyebabkan 50\% kematian Artemia salina. Uji toksisitas terhadap larva udang Artemia salina Leach atau Brine Shrimp Lethallity Test (BSLT) dapat digunakan sebagai uji pendahuluan pada penelitian yang mengarah pada uji sitotoksik [5]. Berdasarkan hasil penelitian dapat diketahui potensi tingkat toksisitas ekstrak etanol daun ekor kucing melalui uji toksisitas terhadap larva udang Artemia salina Leach dengan metode BSLT ini sehingga dapat dilakukan pengujian bioaktivitas lebih lanjut.

\section{Kesimpulan}

Ekstrak etanol daun ekor kucing (Acalpyha hispida Burm.f.) memiliki potensi toksisitas akut terhadap Artemia salina Leach dengan menggunakan metode Brine Shrimp Lethality Test (BSLT) yang ditunjukkan dengan $\mathrm{LC}_{50}$ kurang dari 1.000 ppm. $\mathrm{LC}_{50}$ ekstrak etanol daun ekor kucing (Acalypha hispida Burm.f.) ialah sebesar 220,005 ppm.

\section{Referensi}

[1] DepKes RI. (2007). Lampiran Keputusan Mentri Kesehatan Nomor :381/Menkes/SK/III/2007 mengenai Kebijakan Obat Tradisional Nasional Departemen Kesehatan Republik Indonesia. Jakarta.

[2] KepMenKes RI. (1995). Lampiran Keputusan Mentri Kesehatan Nomor 761/ Menkes/ SK/ IX/ 1992 tentang Pedoman Fitofarmaka. Departemen Kesehatan Republik Indonesia. Jakarta.

[3] Jelita, S.F., Gita, W.S., Michelle, F., Ade, Z., \& Sandra, M. (2020). Uji Toksisitas Infusa Acalypha siamensis Dengan Metode Brine Shrimp Lethality Test (BSLT). Farmaka. Volume 18 - 1. doi : 10.24198/jf.v18i1.25926.

[4] Dalimartha, S. (2007). Atlas Tumbuhan Obat Indonesia Jilid 3. Puspa Swara. Jakarta.

[5] Meyer, H.N. (1982). Brine Shrimp Lethality Test: Med. Plant Research. Vol.45 No. 3. Amsterdam.

[6] Voight, R. (1995). Buku Pelajaran Teknologi Farmasi, (Penerjemah Soedani, N.), (Edisi V). UGM Press. Yogyakarta. hal: 553-555, 572-574.

[7] Arifin, H., Anggraini, N., Handayani, D., dan Rasyid, R. (2006). Standarisasi Ekstrak Etanol Daun Eugenia Cumini Merr. J. Sains Tek. Far., , 11 2: 89, 90.

[8] Sriwahyuni, I. (2010), Uji Fitokimia Ekstrak Tanaman Anting-Anting (Acalypha Indica Linn) dengan Variasi Pelarut dan Uji Toksisitas Menggunakan Brine Shrimp (Artemia salina Leach), [Skripsi], Malang: Fakultas Sains dan Teknologi Universitas Islam Negeri (UIN) Maulana Malik Ibrahim, hal: 15-19, 21, 25-34.

[9] Irianti, T., Puspitasari, A., dan Suryani, E. (2011). Aktivitas Penangkapan Radikal 2,2-difenil-1-pikrilhidrazil oleh Ekstrak Etanolik Batang Brotowali (Tinospora crispa (L.) miers) dan Fraksi-Fraksinya. Majalah Obat Tradisional, , 16 3: 138-144.

[10] Syamsul, E.S. (2012). Uji Aktivitas Antidiabetes, Antihiperlipidemia, dan Antiarterosklerosis Kombinasi Ekstrak Terpurifikasi Herba Sambiloto 
(Andrographis paniculata (Burm.f.) Ness.) dan Metformin pada Tikus Diabetes Mellitus Tipe 2 Resistensi Insulin, Tesis, Fakultas Farmasi Universitas Gadjah Mada, Yogyakarta.

[11] Zuhra, et al. (2008), Aktivitas Antioksidan Senyawa Flavonoid dari Daun Katuk (Sauropus androgunus (L) Merr.), Jurnal Biologi Sumatera 3 (1): 7-10.

[12] Tarumingkeng, R. C. (1992). Insektisida, Sifat, Mekanisme Kerja dan Dampak Penggunaannya. Kanisius. Yogyakarta.

[13] Gokok, S. (2017). Uji Toksisitas Bioinsektisida Ekstrak Metanol Buah Bintaro (Cerbera odollam L.) terhadap Mortalitas Ulat Grayak (Spodoptera litura) pada Pakan Daun Tomat. [Skripsi]. Yogyakarta. Fakultas Keguruan dan Ilmu Pendidikan, Universitas Sanata Dharma.

[14] Dinata, A. (2008). Ekstrak Kulit Jengkol Atas Jentik DBD. Diakses 8 Agustus 2021. http:/ / artikel.prianganonline.com/index.php?act?act $=$ artikel\&aksi $=$ lihat\&id $=27$ 4.

[15] Rita W.S., et.al. (2008). Isolasi \& Identifikasi Senyawa Yang Berpotensi Sebagai Antitumor Pada Daging Buah Pare (Momordica charantia L.). Jurusan Kimia FMIPA Universitas Udayana. Bukit Jimbaran. Jurnal Kimia Vol. 2.

[16] Cahyadi, R. (2009). Uji Toksisitas Akut Ekstrak Etanol Buah Pare (Momordica charantia L.) Terhadap Larva Artemia salina Leach dengan Metode Brine Shrimp Lethality Test (BST). [Skripsi]. Semarang. Fakultas Kedokteran, Universitas Diponegoro. 